\title{
ABNORMAL PROTEIN AND NUCLEIC ACID METABOLISM AS A CAUSE OF CATARACT FORMATION INDUCED BY NUTRITIONAL DEFICIENCY IN RABBITS* $\uparrow$
}

\author{
BY \\ ANIMA DEVI, PIYARA LAL RAINA, AND ANUPINDER SINGH \\ Department of Biochemistry, Postgraduate Institute for Medical Research, Chandigarh, Punjab, India
}

A WIDE variety of nutritional deficiencies producing gradual loss of transparency in the human lens as well as in the lenses of laboratory animals, has been reported (Oomen, 1954; Pirie and van Heyningen, 1956). The development of lenticular opacities and finally the liquefaction of lens fibres are the visible changes among these affected animals (Passmore, 1947). Pathologically, muscular dystrophy in rabbits, induced by vitamin $\mathrm{E}$ deficiency, closely resembles hereditary muscular dystrophy (Mason, 1960). Previously, changes in the nucleic acid and protein metabolism of the lens in hereditary muscular dystrophy had been shown (Srivastava, Devi, and Sarkar, 1963). In the present study cataracts have been induced in rabbits maintained on a vitamin E-deficient diet and the metabolism of nucleic acid and of proteins in the lenses of these animals has been investigated. It is hoped that the results of this investigation may indicate that cataract developed by nutritional deficiency resembles the cataract formed by hereditary dystrophy, although the primary cause of these two diseases is not the same.

\section{Experimental}

Young white rabbits of the New Zealand strain each weighing approximately $1,000 \mathrm{~g}$. were kept separately in metabolic cages on a vitamin E-deficient diet. The composition of the diet was similar to the one previously described by Sarkar and Srivastava (1964). Rabbits of approximately the same age maintained on the same diet supplemented with an adequate amount of vitamin E served as controls. In the recovery experiments, when the disease had progressed 70-80 per cent., a sufficient amount of vitamin E was added to the diet to ensure normal growth. At the specified time animals from the normal and experimental group were sacrificed by decapitation and allowed to bleed. Immediately the eyes from each animal were enucleated. One lens was used for protein and nucleic acid determination, as described by Devi, Srivastava, and Mukundan (1963), and the other was homogenized in buffered media for studying deoxyribonucleic acid (DNA) polymerase activity. The extent of the disease was determined by measuring the ratio of creatine and creatinine in the urinary excretion of these animals as described by Dinning and Day (1957). $C^{14}$ leucine (specific activity $0.8 \times 10^{8} \mathrm{cpm}$./mg. of leucine) and $\mathrm{C}^{14}$ uridine (specific activity

* Received for publication July 7, 1964.

† Part of this work has been carried out at the Department of Biochemistry, Laval University, Quebec, Canada. 
$1 \times 10^{6} \mathrm{cpm}$./mg. of uridine) per $\mathrm{kg}$. body-weight had been intraperitoneally injected into the animals. Since maximum incorporation of the radio-activity in the animals was found at 4 hours (Devi and Sarkar, 1961; Sarkar, Devi, and Hempelmann, 1961), the animals were killed at a specified time and their lenses were homogenized, deproteinized, washed, and counted with windowless gasflow counter according to the method described by Devi, Friel, and Lerman (1961). The activity was expressed as counts per minute per mg. of dry material after correcting the background and self absorption. Ribonucleic acid (RNA) was estimated by Bial's orcinol reaction of pentoses (Webb and Levy, 1958) making allowances for the dichromatic readings as described by Dische, Devi, and Zelmenis (1961). DNA was estimated by the method of Burton (1956). Protein was determined using Nessler's reagent, as described by Lang (1958). For DNA polymerase activity the lens homogenates from normal and dystrophic animals were incubated in the presence of $\mathrm{Mg}^{++}$, triphosphates of all three deoxyribonucleotides (dGTP, dCTP, and dATP*), and $\mathrm{C}^{14}$ thymidine. Heat-denatured two-stranded DNA was used as primer in the system (Sarkar, Okada, and Devi, 1963).

\section{Results}

In Table I the results concerning the changes in weight and protein content of the lenses of normal and dystrophic animals are shown. Four such different sets of experiments were carried out with animals exhibiting 30 per cent., 50-60 per cent., and 90-95 per cent. of the disease. The decrease in lens weight and protein content are 30-33 per cent., 2-17 per cent., and 20-30 per cent. respectively. The results shown in the table also indicate that the decrease in lens protein had started long before the development of the acute stage of the disease.

TABLE I

CHANGE OF WEIGHT AND PROTEIN CONCENTRATION OF THE LENS OF DYSTROPHIC RABBITS

\begin{tabular}{|c|c|c|c|c|c|}
\hline $\begin{array}{c}\text { Experiment } \\
\text { No. }\end{array}$ & $\begin{array}{c}\text { State of } \\
\text { Dystrophy }\end{array}$ & $\begin{array}{l}\text { Weight of } \\
\text { Lens in mg. }\end{array}$ & $\begin{array}{l}\text { Per cent. } \\
\text { Loss }\end{array}$ & $\begin{array}{l}\text { Per cent. } \\
\text { Protein in Lens }\end{array}$ & $\begin{array}{l}\text { Per cent. } \\
\text { Loss }\end{array}$ \\
\hline 1 & $\begin{array}{l}\text { Normal } \\
\text { Dystrophy 5th day } \\
\text { Dystrophy 10th day }\end{array}$ & $\begin{array}{l}280,280 \\
274,283 \\
241,241\end{array}$ & $\begin{array}{c}0-2 \\
13-14\end{array}$ & $\begin{array}{l}25 \cdot 0 \\
28 \cdot 0 \\
20 \cdot 0\end{array}$ & 20 \\
\hline 2 & $\begin{array}{l}\text { Normal } \\
\text { Dystrophy severe }\end{array}$ & $\begin{array}{l}265 \\
220\end{array}$ & 17 & $\begin{array}{l}24 \cdot 8 \\
18 \cdot 6\end{array}$ & 25 \\
\hline 3 & $\begin{array}{l}\text { Normal } \\
\text { Dystrophy severe }\end{array}$ & $\begin{array}{l}290-286 \\
240-235\end{array}$ & 17,17 & $\begin{array}{l}28 \cdot 0 \\
18 \cdot 4\end{array}$ & 37 \\
\hline 4 & $\begin{array}{l}\text { Normal } \\
\text { Dystrophy 1st stage } \\
\text { Dystrophy 2nd stage } \\
\text { Dystrophy 3rd stage } \\
\text { Dystrophy recovered } \\
\text { Control* }\end{array}$ & $\begin{array}{l}260,264 \\
257,261 \\
224,220 \\
218,220 \\
268,249 \\
256,259\end{array}$ & $\begin{array}{r}1-2 \\
11 \cdot 4 \\
16 \cdot 4 \\
1 \cdot 9 \\
1-2\end{array}$ & $\begin{array}{l}26 \cdot 5 \\
28 \cdot 0 \\
19 \cdot 5 \\
20 \cdot 6 \\
20 \cdot 5 \\
24 \cdot 5\end{array}$ & $\begin{array}{l}26 \cdot 4 \\
22 \\
23 \\
8\end{array}$ \\
\hline
\end{tabular}

* Rabbits with vitamin E-supplemented diet

A comparison of RNA concentrations in the lenses of normal and dystrophic animals (Table II) reveals a steady increase in RNA content per unit weight tissue or per $100 \mathrm{~g}$. lens protein amounting to $10-11$ per cent., 33-34 per cent., and 76-108 per * dGTP $=$ deoxyribose guanosine triphosphate; $d C T P=$ deoxyribose cytosine triphosphate; $d A T P=$ deoxyribose adenosine
triphosphate. 
TABLE II

NUCLEIC ACID (RNA) CONTENT IN THE LENS OF MUSCULAR DYSTROPHIC RABBITS

\begin{tabular}{|c|c|c|c|c|c|}
\hline $\begin{array}{l}\text { Experiment } \\
\text { No. }\end{array}$ & $\begin{array}{l}\text { State of } \\
\text { Dystrophy }\end{array}$ & $\begin{array}{c}\text { RNA } \\
\mu \mathrm{g} . / 100 \mathrm{~g} . \\
\text { Lens }\end{array}$ & $\begin{array}{l}\text { Per cent. } \\
\text { Increase }\end{array}$ & $\begin{array}{l}\text { RNA } \\
\mu \mathrm{g} . / 100 \mathrm{~g} . \\
\text { Protein }\end{array}$ & $\begin{array}{l}\text { Per cent. } \\
\text { Increase }\end{array}$ \\
\hline 1 & $\begin{array}{l}\text { Normal } \\
\text { Dystrophy 5th day } \\
\text { Dystrophy 10th day }\end{array}$ & $\begin{array}{r}64 \\
87 \\
173\end{array}$ & $\begin{array}{l}35-36 \\
170\end{array}$ & $\begin{array}{l}256 \cdot 0 \\
310 \cdot 7 \\
865\end{array}$ & 237 \\
\hline 2 & $\begin{array}{l}\text { Normal } \\
\text { Dystrophy severe }\end{array}$ & $\begin{array}{l}138 \\
184\end{array}$ & $33-34$ & $\begin{array}{l}556 \cdot 4 \\
989\end{array}$ & 76 \\
\hline 3 & $\begin{array}{l}\text { Normal } \\
\text { Dystrophy severe }\end{array}$ & $\begin{array}{l}140 \\
187\end{array}$ & $33-34$ & $\begin{array}{r}500 \\
1,014\end{array}$ & 102 \\
\hline 4 & $\begin{array}{l}\text { Normal } \\
\text { Dystrophy 1st stage } \\
\text { Dystrophy 2nd stage } \\
\text { Dystrophy 3rd stage } \\
\text { Dystrophy recovered } \\
\text { Control* }^{*}\end{array}$ & $\begin{array}{l}100 \\
109 \\
110 \\
163 \\
144 \\
106\end{array}$ & $\begin{array}{r}9 \\
10 \\
63 \\
44 \\
6\end{array}$ & $\begin{array}{l}373 \\
389 \\
564 \\
791 \\
702\end{array}$ & $\begin{array}{c}4-5 \\
51 \cdot 2 \\
112 \\
115\end{array}$ \\
\hline
\end{tabular}

* Rabbits with vitamin E-supplemented diet

cent. respectively during the progress of the disease. In the recovery stage, although RNA concentration tends to approach the normal value, a complete recovery is not achieved. Initially DNA concentration (expressed as $\mu \mathrm{g} . / \mathrm{mg}$. of lens) in normal and dystrophic animals slightly decreases, but at a later stage a significant rise (2- to 5 -fold) is observed. The in vivo incorporation of $\mathrm{C}^{14}$ leucine in lens protein is increased with the progress of the disease amounting to $40-45$ per cent. at $60-65$ per cent. dystrophy. The increased incorporation does not, however, decline to its normal values when the animal is in the recovery stage. $\mathrm{C}^{\mathbf{1 4}}$ uridine incorporation in lens RNA is found to be increased by 30-35 per cent. only at 60-65 per cent. dystrophy. In the recovery process it starts declining but does not come back to its normal value. The results of the incorporation of $\mathrm{C}^{14}$ thymidine, using heatdenatured two-stranded DNA as a primer in the presence of triphosphates of all four deoxyribonucleotides, are shown in Table III. DNA polymerase activity is also increased by $50-60$ per cent. in the lenses of severely affected animals.

TABLE III

DNA POLYMERASE ACTIVITY IN THE LENS OF DYSTROPHIC RABBITS

\begin{tabular}{c|l|c|c}
\hline \multirow{2}{*}{ Experiment No. } & \multirow{2}{*}{ State of Dystrophy } & \multicolumn{2}{|c}{ Cpm./100 mg. of Lens Material } \\
\cline { 2 - 4 } & & Cpm. & Per cent. Increase \\
\hline \multirow{2}{*}{1} & Normal & 946 & $65 \cdot 5$ \\
\hline \multirow{2}{*}{2} & Dystrophy severe & 1,568 & $70 \cdot 5$ \\
\cline { 2 - 4 } & Normal \\
Dystrophy severe & 839 & $65 \cdot 6$ \\
\cline { 2 - 4 } & Normal & 1,465 & 66.8 \\
\hline
\end{tabular}




\section{Discussion}

A few illustrations showing the defects in the lenses of those animals maintained on vitamin E-deficient diet are available in the literature (Zacharias, Goldhaber, and Kinsey, 1950). The only defect so far observed is in the turkey, involving the progressive liquefaction of lens fibres and the degeneration of lens epithelium (Ferguson, Rigdon, and Couch, 1956). The appearance of cloudiness in the lens of the turkey embryo maintained on vitamin E-deficient diet was also noted by Atkinson, Ferguson, Quisenberry, and Couch (1955). It seems therefore that the depletion of vitamin $\mathrm{E}$ from the diet may cause serious defects in vision.

The present study shows a lenticular opacity as an effect of nutritional deficiency. The development of opacity is complete when the animals are affected severely, at which state the eyelids are almost closed and the animals are unable to open them even by external stimulation. This is probably due to the inability of the contractile protein (partícularly myosin) to work properly in the musculature of the eyelids, as has been shown in the muscles of such diseased animals (Horvath, 1958). Since the incorporation of $\mathrm{C}^{14}$ amino-acids in lens protein is increased by $40-45$ per cent. in the affected animals a defect in the protein synthesis mechanism can be excluded. Although lens RNA is composed of all types of RNA which are involved in protein synthesis, it is still uncertain which RNA is actually increased and how this increase is related to the observed rate of protein synthesis in this study. It is conceivable that the increased rate of protein synthesis would demand an increased rate of RNA synthesis, which is indeed the case. The elevation of RNA synthesis partly accounts for the observed increase in RNA content of the diseased lens. If, on the other hand, ribonuclease and deoxyribonuclease activities also decrease in the lenses of affected animals, it may be possible that the turnover rate of RNA and DNA would gradually decrease and these nucleotides would ultimately accumulate at a slow rate. Until now it is not known whether ribonuclease or deoxyribonuclease is increased in such diseased lenses. The investigation of these two enzymes in the lenses of dystrophic animals is in progress in this laboratory.

The fact that lens fibres undergo extensive degradation and eventually disappear in severe dystrophy, in spite of the ability of the lens to synthesize protein at an increased rate, certainly suggests that a factor or factors other than the synthesizing machinery plays an important role in the progress of the disease that brings about the dissolution of lens protein. This aspect remains to be investigated.

Finally, a comparison is made (Table IV) of the results obtained in this study of the protein and nucleic acid metabolism in the lenses of dystrophic rabbits maintained

TABLE IV

COMPARISON OF NUCLEIC ACID AND PROTEIN METABOLISM IN THE LENSES OF DYSTROPHIC RABBITS AND DYSTROPHIC MICE

\begin{tabular}{l|c|c|c|c}
\hline Animal & $\begin{array}{c}\text { Per cent. Decrease } \\
\text { Protein }\end{array}$ & $\begin{array}{c}\text { Per cent. Increase } \\
\text { RNA }\end{array}$ & $\begin{array}{c}\text { Per cent. Increase } \\
\text { DNA }\end{array}$ & $\begin{array}{c}\text { Per cent. Increase } \\
\text { DNA Polymerase }\end{array}$ \\
\hline Rabbits & $25-37$ & $35-45$ & $150-200$ \\
Mice & $30-35$ & $100-110$ & $150-200$ & $60-70$ \\
& & & $65-70$ \\
\hline
\end{tabular}


on vitamin E-deficient diet, with the results obtained in the case of the lenses in hereditary dystrophic mice (Devi, Srivastava, and Mukundan, 1963). It is evident that the pattern of changes in protein and nucleic acid metabolism is of the same nature. It might indicate that, although the primary cause of the disease is a nutritional deficiency in one and a genetic defect in the other, the secondary manifestations appear to be similar.

\section{Summary}

A progressive cataract has been developed in rabbits maintained on a vitamin E-deficient diet. Nucleic acids from the lenses of normal and dystrophic animals (30 per cent., 60 per cent., and 90 per cent. dystrophy) have been separately determined. The protein and RNA synthesis (in vivo) and DNA synthesis (in vitro) have been carried out by intraperitoneal injection of $\mathrm{C}^{14}$ leucine and $\mathrm{C}^{\mathbf{1 4}}$ uridine into the animals, and by $\mathrm{C}^{\mathbf{1 4}}$ thymidine incorporation into lens homogenate. A 30-40 per cent. decrease in total protein has been observed with the progress of deficiency. A relative increase of the synthesis of protein and ribonucleic acid, as judged by the incorporated radio-active amino-acid and nucleotide, has also been noticed. The enzyme DNA polymerase, which is known to be involved in the synthesis of DNA, has been found to be increased in activity with the progress of the disease, and the increase in activity reaches a maximum at 90 per cent. dystrophy.

\section{REFERENCES}

Atkinson, R. L., Ferguson, T. M., Quisenberry, J. R., and Couch, J. R. (1955). J. Nutr., $55,387$.

Burton, K. (1956). Biochem. J., 62, 315.

Devi, A., Friel, R., and Lerman, S. (1961). Arch. Ophthal. (Chicago), 65, 855. and SARKAR, N. K. (1961). Nature (Lond.), 191, 1094.

-, Srivastava, U., and Mukundan, M. A. (1963). Invest. Ophthal., 2, 519.

Dinning, J. S., and DAY, P. L. (1957). J. Nutr., 83, 193.

Dische, Z., Devi, A., and Zelmenis, G. (1961). Amer. J. Ophthal., 51, 994. (No. 5, pt. 2).

Ferguson, T. M., Rigdon, R. H., and Couch, J. R. (1956). A.M.A. Arch. Ophthal., 55, 346.

Horvath, B. (1958). Neurology (Minneap.), 8, Suppl. (Sect. Neurochem. Amer. Acad. Neurol.), p. 52.

LANG, C. A. (1958). Analyt. Chem., 30, 1692.

Mason, K. E. (1960). In "The Structure and Function of Muscle", ed. G. H. Bourne, vol. 3, chap. 6, p. 171. Academic Press, New York.

OOMEN, H. A. P. C. (1954). Brit. J. Nutr., 8, 307.

Passmore, R. (1947). Trans. roy. Soc. trop. Med. Hyg., 41, 189.

Pirie, A., and van.Heyningen, R. (1956). "Biochemistry of the Eye", p. 278. Blackwell, Oxford.

Sarkar, N. K., and Srivastava, U. (1964). J. Nutr., 83, 193.

- Devi, A., and Hempelmann, L. H. (1961). Nature (Lond.), 192, 179.

-, Okada, S., and Devi, A. (1963). Exp. Cell. Res., 29, 36.

Srivastava, U., Devi, A., and Sarkar, N. K. (1963). Ibid., 29, 289.

WebB, J. M., and LeVY, H. B. (1958). In "Methods of Biochemical Analysis", ed. D. Glick, vol. 6, p. 1. Interscience Publications, New York.

Zacharias, L., Goldhaber, P., and KinSEY, V. E. (1950). J. Nutr., 42, 359. 